\title{
Recent patents in nanotechnology
}

\begin{tabular}{|c|c|c|c|c|c|}
\hline Patent \# & Subject & Assignee & Inventor(s) & $\begin{array}{l}\text { Priority } \\
\text { application date }\end{array}$ & $\begin{array}{c}\text { Publication } \\
\text { date }\end{array}$ \\
\hline WO 200291028 & $\begin{array}{l}\text { A system using nanoscale colloidal particles to realize } \\
\text { photonic and microfluidic devices, including two-way, } \\
\text { three-way, multidimensional, or check valves, and peri- } \\
\text { staltic, rotary, vane, or two-lobe gear pumps; useful for } \\
\text { interfacing integrated-circuit techniques with chemical } \\
\text { and/or biological systems on micro-patterned substrates, } \\
\text { to produce 'lab-on-a-chip' devices for bioanalysis, medi- } \\
\text { cal diagnosis, and therapeutic treatment. }\end{array}$ & $\begin{array}{l}\text { Colorado School } \\
\text { of Mines } \\
\text { (Golden, CO) }\end{array}$ & $\begin{array}{l}\text { Gong T, } \\
\text { Marr DWM, } \\
\text { Oakey J, } \\
\text { Terray AV }\end{array}$ & $5 / 8 / 2001$ & $11 / 14 / 2002$ \\
\hline WO 200290770 & $\begin{array}{l}\text { A microfluidic distribution unit having two reaction } \\
\text { chambers, into which a fluid can be pushed using non- } \\
\text { mechanically induced volumetric changes; used for the } \\
\text { propulsion of a liquid in a nanoscale device. }\end{array}$ & $\begin{array}{l}\text { NanoLab } \\
\text { (Watertown, MA) }\end{array}$ & $\begin{array}{l}\text { Kaplan S, } \\
\text { Shacham A }\end{array}$ & $5 / 7 / 2001$ & $11 / 14 / 2002$ \\
\hline US 20020153046 & $\begin{array}{l}\text { A fluid flow splitting device for a multi-stream microfluidic } \\
\text { device; ensures precise division of established flows of } \\
\text { fluids, thus enabling passive control of the fluid flow } \\
\text { through the microfluidic channel. }\end{array}$ & $\begin{array}{l}\text { Nanostream } \\
\text { (Pasadena, CA) }\end{array}$ & $\begin{array}{l}\text { Dantsker E, } \\
\text { Hobbs SE, } \\
\text { Karp CD, Patel PP, } \\
\text { Pezzuto M }\end{array}$ & 9/25/2001 & $10 / 24 / 2002$ \\
\hline WO 200280365 & $\begin{array}{l}\text { A molecular device with an internal charge transfer carrier; } \\
\text { useful for performing memory or logic functions in electronic } \\
\text { and optoelectronic systems using molecular electrostatic } \\
\text { potential created based on the perturbation of molecules. }\end{array}$ & $\begin{array}{l}\text { Penn State Univ. } \\
\text { Research Foundation } \\
\text { (University Park, PA) }\end{array}$ & Jackson TN & $3 / 30 / 2001$ & 10/10/2002 \\
\hline WO 200280194 & $\begin{array}{l}\text { A quantum nanowire that comprises a macromolecular } \\
\text { matrix (comprising dipoles, dopant, and free electrons); } \\
\text { useful in microelectronics, optoelectronics, or biomed- } \\
\text { icine, preferably for the manufacture of semiconductor } \\
\text { devices, temperature and pressure sensors, switches, } \\
\text { diodes, motors, optical switches, piezoelectric devices, } \\
\text { trinary computer devices, optical detectors, or other } \\
\text { devices for which small size and low power consumption } \\
\text { are desirable features. }\end{array}$ & $\begin{array}{l}\text { Quantum Polymer } \\
\text { Technologies } \\
\text { (Santa Rosa, CA) }\end{array}$ & $\begin{array}{l}\text { Grigorov LN, } \\
\text { Talroze R }\end{array}$ & $1 / 23 / 2001$ & 10/10/2002 \\
\hline WO 200277604 & $\begin{array}{l}\text { A stabilized cell for use as an internal control in methods } \\
\text { for isolating and identifying rare cells (for example, } \\
\text { cancer cells). The method involves obtaining a blood } \\
\text { sample suspected of containing the rare cells from a test } \\
\text { subject and mixing the sample with coated magnetic } \\
\text { nanoparticles coupled to a ligand that reacts specifically } \\
\text { with a determinant of the rare cells to the substantial } \\
\text { exclusion of other sample components. }\end{array}$ & $\begin{array}{l}\text { Immunivest } \\
\text { (Wilmington, DE) }\end{array}$ & $\begin{array}{l}\text { Liberti PA, } \\
\text { Rao GC, } \\
\text { Rutner H, } \\
\text { Terstappen LWMM }\end{array}$ & $\begin{array}{l}3 / 8 / 2001 \\
M\end{array}$ & $10 / 3 / 2002$ \\
\hline WO 200275273 & $\begin{array}{l}\text { A screening and diagnostic method of an agonist or } \\
\text { antagonist for a calcium-coupled receptor; involves in- } \\
\text { cubating one or more cells expressing apoaequorin to } \\
\text { reconstitute active aequorin, contacting the cells with } \\
\text { the agonist or antagonist, and measuring the light emitted } \\
\text { by the cells on a solid support. This high-throughput } \\
\text { method facilitates a functional screen using very few } \\
\text { (down to 100) cells per measurement due to the high } \\
\text { sensitivity of charge-coupled device (CCD)-cameras } \\
\text { present in the luminometer. }\end{array}$ & $\begin{array}{l}\text { Euroscreen } \\
\text { (Brussels, Belgium) }\end{array}$ & $\begin{array}{l}\text { Dupriez V, } \\
\text { Parmentier M }\end{array}$ & $3 / 20 / 2001$ & 9/26/2002 \\
\hline WO 200274431 & $\begin{array}{l}\text { A process for preparing coated particles comprises coating } \\
\text { template particles with single- or multi-layers of polymers } \\
\text { and/or polyelectrolytes, and exposing the coated part- } \\
\text { icles to an organic molecular precursor. Coated particles } \\
\text { can contain an active agent such as a pharmaceutical, } \\
\text { contrasting agent, herbicide, pesticide, catalyst, or pigment. }\end{array}$ & $\begin{array}{l}\text { Max Planck Society } \\
\text { for the Advancement } \\
\text { of Science (Munich, } \\
\text { Germany) }\end{array}$ & Caruso F & $3 / 21 / 2001$ & 9/26/2002 \\
\hline WO 200260812 & $\begin{array}{l}\text { A method of producing a solution of single-wall carbon nano- } \\
\text { tubes comprising the derivatization of single-wall carbon } \\
\text { nanotubes followed by the dispersing of the derivatized } \\
\text { nanotubes in a solvent; useful in making a polymer material. }\end{array}$ & $\begin{array}{l}\text { Rice University } \\
\text { (Houston, TX) }\end{array}$ & $\begin{array}{l}\text { Bahr JL, } \\
\text { Tour JM, } \\
\text { Yang J }\end{array}$ & $8 / 31 / 2001$ & 8/8/2002 \\
\hline
\end{tabular}

Source: Derwent Information, Alexandria, VA. The status of each application is slightly different from country to country. For further details, contact Derwent Information, 1725 Duke Street, Suite 250, Alexandria, VA 22314. Tel: 1 (800) DERWENT (info @ derwent.com). 